\title{
CASE STUDY ON THE RELATIONSHIPS BETWEEN SOIL CONTENTS OF SOME HARMFUL CHEMICAL ELEMENTS DETERMINED BY DIFFERENT EQUIPMENT
}

\author{
Rimantė Zinkutė, Ričardas Taraškevičius
}

Nature Research Centre Institute of Geology and Geography

13 T. Ševčenkos st., Vilnius, LT-03223, Lithuania

Ph.: +(370)52104708, fax: +(370)52104695, e-mail: zinkute@geo.lt, taraskevicius@geo.lt

\begin{abstract}
Comparison of total contents of $\mathrm{Ba}, \mathrm{Cr}, \mathrm{Cu}, \mathrm{Mn}, \mathrm{Mo}, \mathrm{Ni}, \mathrm{Sn}, \mathrm{Pb}, \mathrm{V}, \mathrm{Zn}, \mathrm{Al}, \mathrm{Ca}, \mathrm{Fe}, \mathrm{Mg}$ determined in topsoil of central part of Vilnius by optical atomic emission spectrophotometry (OAES) with respective contents determined by energy-dispersive $x$-ray fluorescence (EDXRF), analysis of their correlation and linear relationship with and without outliers are the tasks of research. For most elements, except Ca, Sn, $\mathrm{Ba}$, the contents determined by EDXRF are significantly lower and less variable. They can be predicted according to OAES-contents using linear equations. After elimination of outliers for all elements the correlation is significant at $p<0.05$.
\end{abstract}

Keywords: optical atomic emission spectrophotometry, energy-dispersive $x$-ray fluorescence, urban soil, chemical elements.

\section{Introduction}

Until 2007 all geochemical investigations at the Institute of Geology and Geography (IGG) were based on the total contents of trace elements determined by optical atomic emission spectrophotometry (OAES) using DFS-13 equipment. This equipment was used both for determination of soil background values [1-4] and for urban geochemical mapping [5-8]. So the results obtained in IGG before 2007 can be compared. In urban topsoil investigations the following potentially toxic trace elements were usually determined: $\mathrm{Ag}, \mathrm{B}, \mathrm{Ba}, \mathrm{Co}, \mathrm{Cr}, \mathrm{Cu}$, $\mathrm{Mn}, \mathrm{Mo}, \mathrm{Ni}, \mathrm{Pb}, \mathrm{Sn}, \mathrm{V}, \mathrm{Zn}$. Since 1997 the laboratory has been participating with OAES in "International Soil-analytical exchange" (ISE) program organised by Wageningen University. In 2007 new energy-dispersive x-ray fluorescence (EDXRF) equipment SPECTRO XEPOS was purchased and IGG started to participate in ISE with EDXRF. Using TURBOQUANT calibration method for pressed pellets the total contents of chemical elements from $\mathrm{Na}$ to $\mathrm{U}$ can be determined.

Aiming to compare the results obtained by EDXRF and OAES equipment, it is necessary to re-analyse old samples by EDXRF. Case study of the relationships between urban soil contents of $\mathrm{Ba}, \mathrm{Cr}, \mathrm{Cu}, \mathrm{Mn}, \mathrm{Mo}, \mathrm{Ni}, \mathrm{Pb}, \mathrm{Sn}, \mathrm{V}, \mathrm{Zn}$, determined by OAES (OAES-contents) and EDXRF (EDXRF contents) is the object of this research. The relationships between OAES-contents and EDXRF-contents of major elements $\mathrm{Al}, \mathrm{Fe}, \mathrm{Ca}, \mathrm{Mg}$ are also analysed.

\section{Materials and methods}

Composite topsoil samples were taken in 2006 from 141 site in central part of Vilnius. Each sample was gathered by collecting 20-25 similar mass increments, homogenised and reduced to $1 \mathrm{~kg}$. Then the samples were sieved through $1 \mathrm{~mm}$ sieve, ashed at $300-350^{\circ} \mathrm{C}$ and milled. OAES-contents of 13 trace and 4 major elements ( $\mathrm{Al}, \mathrm{Ca}, \mathrm{Fe}$ and $\mathrm{Mg}$ ) were determined by vaporization of $0.5 \mathrm{~g}$ of fine-milled soil at $5000-6000^{\circ} \mathrm{C}$ in the electric arc between three graphite nails; determination was done by optical spectrophotometer DFS 13. The results obtained by this type of analysis have been already discussed analysing the distribution of harmful trace elements both in the oldest part of Vilnius [9] and in younger districts [10]. 
In 2010 real total contents of large group of major or trace elements were determined in the same samples by EDXRF [11]. Sample preparation for this analysis was as follows: the sieved samples were milled with MM 400, homogenised with Licowax (4 g of sample and $0.9 \mathrm{~g}$ of wax) and pressed with PP15 press into $32 \mathrm{~mm}$ pellets. The primary content of chemical elements in each pellet was determined using SPECTRO XEPOS equipment and TURBOQUANT for pressed pellets calibration method. Total number of measurements was 282 , as for each sample two pellets were prepared. The contents of almost all the elements, which are the object of this research, were above their DL in all pellets, the only exception was Mo: in $74.4 \%$ of pellets its content was below DL. Great part of undefined measurements of Mo was a serious obstacle for comparison of its results obtained by two methods. In order to have database without missing values, the value $0.1 \mathrm{ppm}$ was inserted for primary measurements of those pressed pellets where Mo content was below DL. Median content of each element in each sample was calculated according to measurements of two pellets. The primary median measurement values in each sample were recalibrated using 44 ISE reference samples, CRM 2709 and CRM 2711. In all cases, except Al, linear regression was used for this aim with coefficient of determination higher than 0.9 .

The estimates of relative standard measurement uncertainties for the mean contents of 10 trace elements $U_{m}(\%)$ determined by different equipment are given below. For EDXRF, these values $\left(\mathrm{U}_{\mathrm{m}-\mathrm{EDXRF}}\right)$ were estimated according to 56 (for Mo 46) repeated measurements of CRM 2709 during the first quarter of 2010. $\mathrm{U}_{\mathrm{m} \text {-EDXRF }}$ values of 14 trace and 10 major elements did not exceed 5\%, though respective uncertainties for individual measurements ( $\left.\mathrm{U}_{\text {ind-EDXRF }}\right)$ were higher and for $\mathrm{V}, \mathrm{Sn}$, Mo exceeded 5\% [11]. As concerns trace elements of this research, $\mathrm{U}_{\mathrm{m}-\mathrm{EDXRF}}$ values were the following: $\mathrm{Zn}(0.09), \mathrm{Mn}(0.11), \mathrm{Ni}(0.15), \mathrm{Pb}(0.28)$, $\mathrm{Ba}(0.31), \mathrm{Cu}(0.50), \mathrm{Cr}(0.5), \mathrm{V}(0.81), \mathrm{Mo}(4.96), \mathrm{Sn}(1.66)$. For OAES, the $\mathrm{U}_{\mathrm{m}-\mathrm{OAES}}$ values (\%) were estimated in 2004 according to 22 repeated measurements of another sample (ISE No.921). All these values were also below 5\%. Though element contents in CRM 2709 and ISE No.921 differ and this can influence repeatability, preliminary comparison of $U_{m}$ values

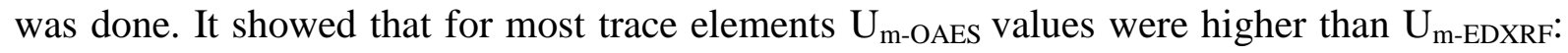
Zn (11 times), Mn(7.28 times), Ni(6.97 times), $\mathrm{Pb}$ (3.69 times), $\mathrm{Ba}(2.48$ times), $\mathrm{Cu}(2.09$ times), $\mathrm{Cr}(2.01$ times), $\mathrm{V}(1.05$ times). Only for 2 elements from 10 they were lower than the values of $\mathrm{U}_{\mathrm{m} \text {-EDXRF: }} \mathrm{Mo}$ (4.65 times), $\mathrm{Sn}$ (1.63 times). Though in regression models usually more precise variables are taken as independent, namely OAES-content was chosen as independent variable because the number of soil samples in Lithuania analysed by EDXRF is still low, besides, for Mo and $\mathrm{Sn}$ the $\mathrm{U}_{\mathrm{m}-\mathrm{OAES}}$ are lower. The latter 2 elements as well as $\mathrm{Cr}$ and $\mathrm{V}$ are characterised also by the highest joint uncertainty from trace elements of this research (arising during EDXRF measurement and sample preparation), this uncertainty exceeds 5\% [11]. According to increasing joint uncertainty the elements are arranged as follows: $\mathrm{Al}(0.95)$ $<\mathrm{Fe}(1.13)<\mathrm{Zn}(1.79)<\mathrm{Mn}(1.90)<\mathrm{Mg}(2.03)<\mathrm{Ba}(2.26)<\mathrm{Ca}(2.50)<\mathrm{Ni}(3.29)<\mathrm{Cu}(3.86)$ $<\mathrm{Pb}(4.10)<\mathrm{Sn}(6.14)<\mathrm{Cr}(10.3)<\mathrm{V}(15.0)<\mathrm{Mo}(66.7)$.

To reveal for each chemical element the differences between 2 variables measured in the same samples (OAES-content and EDXRF-content), two non-parametric tests were used: Sign test and Wilcoxon matched pair test. Pearson correlation coefficients were determined between OAES-content and EDXRF-content. Linear regression model (a - coefficient before independent variable, i.e. slope, $\mathrm{b}$ - intercept) was used to find out the relationships between these contents. The suitability of this model was checked according to p-value of F-test in ANOVA table. To test the null-hypothesis that regression parameters do not differ from zero, $\mathrm{p}$-values of t-test were checked. The level of significance in all tests was 0.05 . If $\mathrm{p}$-values of F-test and t-test are lower than 0.05, the linear equations can be used for prediction of EDXRF-contents according to OAES-contents. When analysing the relationships between different contents, the outliers were revealed and eliminated. There were two consecutive stages of elimination of outliers. The first one was elimination of considerable outliers. The 
sample measurement (case) was supposed to be considerable outlier, when at least one of 3 criteria was fulfilled: 1) absolute value of standard residual of this case was higher than 3 [12]; 2) Cook's distance exceeded the critical value (as the number of cases was always higher than 120 , the $F_{0.5}(2, \infty)=0.693$ was chosen [12]); 3) there was noticeable deviation of this case from the line $y=x$ in the graph "residual versus deleted residual". The second stage (realised after the first stage) was elimination of inconsiderable outliers, i.e. the cases for which the value of standard residual was in the interval [2-3] or which were characterized by less noticeable deviation from the line $\mathrm{y}=\mathrm{x}$ in the graph "residual versus deleted residual". Higher standard residuals indicate cases with the deviation from regression line. Both Cook's distance and deleted residual are measures of impact of the respective case on the regression equation. Cook's distance indicates the difference between the computed values of slope and the values one would have obtained, had the respective case been excluded. If it exceeds critical value [12], there is reason to believe that the respective case biased the estimation of the regression coefficients. If the deleted residual differs greatly from the respective residual value (this can be seen from the graph), then this case is possibly an outlier because its exclusion changed the regression equation. The minimum and maximum values of OAEScontent and EDXRF-content were determined according to all data, according to data after the first stage and after the second stage of elimination.

\section{Results and discussion}

The contents of 11 chemical elements determined by EDXRF are lower than respective contents obtained by OAES. For $\mathrm{Al}, \mathrm{Fe}, \mathrm{Mn}$ and $\mathrm{Ni}$ this regularity is observed in all samples (Table 1). For other 7 chemical elements the percentage of samples where the content determined by EDXRF is lower than the content determined by OAES exceeds 50\%, according to this percentage the latter elements are arranged as follows: $\mathrm{V}(99.3)>\mathrm{Mg}(95.7)>\mathrm{Cr}(95.0)>\mathrm{Pb}(91.5)>\mathrm{Cu}(90.1)>\mathrm{Mo}(88.7)>\mathrm{Zn}(85.1)$. These 11 chemical elements are characterized by higher median OAES-content than median EDXRF-content, all of them, except $\mathrm{Pb}$ and $\mathrm{Cu}$, have also higher maximum AOES-content than maximum EDXRF-content.

Only $\mathrm{Ca}$, Sn and $\mathrm{Ba}$ are distinguished by the opposite regularity, i.e. higher percentage of samples where OAES-content is lower than EDXRF-content. The opposite tendency is especially characteristic of $\mathrm{Ca}$, which has lower median OAES-content than median EDXRFcontent and lower maximum OAES-content than maximum EDXRF-content. For almost all chemical elements there are significant $(\mathrm{p}<0.05)$ differences between OAES-content and EDXRF-content both according to Sign test and according to Wilcoxon matched-pairs test. For $\mathrm{Ba}$ the differences according to both tests are insignificant, for Sn they are insignificant according to Sign test.

For most chemical elements (except $\mathrm{Cu}, \mathrm{Pb}$ and $\mathrm{V}$ ) the variation coefficients of OAEScontents are higher than of EDXRF-contents.

For all trace elements Pearson correlation coefficients $\mathrm{R}$ between OAES-contents and EDXRF-contents are significant $(\mathrm{p}<0.05)$ both before and after elimination of outliers though not all coefficients of determination $\mathrm{R}^{2}$ are higher than 0.25 (Table 2). For example, Mn has low $\mathrm{R}^{2}$ both before and after elimination of outliers, Ba and $\mathrm{V}-$ after elimination of outliers. Trace elements in Table 2 are arranged according to decreasing $\mathrm{R}^{2}$ (and $\mathrm{R}$ ) values of linear regression obtained according to data without elimination of outliers.

Linear regression analysis performed according to primary data of trace elements (without any elimination of outliers) as well as after elimination of outliers showed significant $p$-values of ANOVA F-test (the same as p-values of t-test for slope), also significant p-values for intercept. 
In most cases the elimination of outliers according to deviations from line in the graph "residual versus deleted residual" is realised in the first stage, but for $\mathrm{Mo}, \mathrm{Pb}$ and $\mathrm{Cu}$ also in the second stage.

Comparison of chemical element contents obtained by OAES and EDXRF

\begin{tabular}{|c|c|c|c|c|c|c|c|c|c|c|c|c|}
\hline El. & $\begin{array}{c}\text { Md1 } \\
(\mathbf{p p m})\end{array}$ & $\begin{array}{c}\text { Md2 } \\
(\mathbf{p p m})\end{array}$ & $\begin{array}{c}\text { Mx1 } \\
(\mathbf{p p m})\end{array}$ & $\begin{array}{c}\text { Mx2 } \\
(\mathrm{ppm})\end{array}$ & $\begin{array}{l}\text { VK1 } \\
(\%)\end{array}$ & $\begin{array}{l}\text { VK2 } \\
(\%)\end{array}$ & $\begin{array}{l}\text { Md1/ } \\
\text { Md2 }\end{array}$ & $\begin{array}{l}\text { Mx1/ } \\
\text { Mx2 }\end{array}$ & $\begin{array}{l}\text { VK1/ } \\
\text { VK2 }\end{array}$ & $\begin{array}{l}\text { PL } \\
(\%)\end{array}$ & $\mathbf{S}$ & $\mathbf{W}$ \\
\hline $\mathrm{Ca}$ & 19600 & 20600 & 46800 & 52000 & 34.3 & 32.6 & 0.95 & 0.90 & 1.05 & 36.2 & $*$ & $*$ \\
\hline $\mathrm{Mg}$ & 7370 & 4900 & 114000 & 10100 & 115 & 25.3 & 1.50 & 11.29 & 4.54 & 95.7 & $*$ & $*$ \\
\hline $\mathrm{Al}$ & 38000 & 20100 & 52300 & 27300 & 13.4 & 11.5 & 1.89 & 1.92 & 1.16 & 100.0 & $*$ & $*$ \\
\hline $\mathrm{Fe}$ & 16000 & 8790 & 32800 & 23800 & 21.4 & 20.9 & 1.82 & 1.37 & 1.03 & 100.0 & $*$ & $*$ \\
\hline $\mathrm{Ba}$ & 320 & 316 & 908 & 653 & 30.3 & 15.3 & 1.01 & 1.39 & 1.98 & 49.6 & $\mathrm{~ns}$ & $\mathrm{~ns}$ \\
\hline $\mathrm{Cr}$ & 30.9 & 19.6 & 204 & 95.7 & 60.6 & 50.6 & 1.58 & 2.13 & 1.20 & 95.0 & $*$ & $*$ \\
\hline $\mathrm{Cu}$ & 32.6 & 20.9 & 232 & 273 & 72.6 & 107 & 1.56 & 0.85 & 0.68 & 90.1 & $*$ & $*$ \\
\hline $\mathrm{Mn}$ & 509 & 300 & 977 & 495 & 24.1 & 16.8 & 1.70 & 1.98 & 1.44 & 100.0 & $*$ & $*$ \\
\hline Mo & 1.06 & 0.61 & 178 & 58.5 & 516 & 385 & 1.75 & 3.04 & 1.34 & 88.7 & $*$ & $*$ \\
\hline $\mathrm{Ni}$ & 15.9 & 8.30 & 47.6 & 27.8 & 32.9 & 31.6 & 1.91 & 1.71 & 1.04 & 100.0 & $*$ & $*$ \\
\hline $\mathrm{Pb}$ & 60.0 & 43.8 & 914 & 13100 & 108 & 770 & 1.37 & 0.07 & 0.14 & 91.5 & $*$ & $*$ \\
\hline $\mathrm{Sn}$ & 5.09 & 6.14 & 49.9 & 38.0 & 81.7 & 58.7 & 0.83 & 1.31 & 1.39 & 41.8 & $\mathrm{~ns}$ & $*$ \\
\hline $\mathrm{V}$ & 35.6 & 14.4 & 137 & 59.7 & 42.7 & 58.0 & 2.48 & 2.30 & 0.74 & 99.3 & $*$ & $*$ \\
\hline $\mathrm{Zn}$ & 228 & 133 & 1000 & 530 & 66.7 & 59.3 & 1.71 & 1.90 & 1.13 & 85.1 & $*$ & $*$ \\
\hline
\end{tabular}

Explanation: El. - chemical elements, Md1, Mx1, VK1 - median, maximum and coefficient of variation of OAES-content, respectively; Md2, Mx2, VK1 - median, maximum and coefficient of variation of EDXRF-content, respectively; Md1/Md2, Mx1/Mx2, VK1/VK2 - ratios of respective characteristics; PL - percentage of samples where EDXRF-content is lower than OAES-content; S, $\mathrm{W}$ - characterization of $\mathrm{p}$ values obtained by Sign test or Wilcoxon test $(*-$ significant, i.e. $\mathrm{p}<0.05$, ns - not significant). High contents are rounded.

Only for $\mathrm{Cu}, \mathrm{Sn}$ and $\mathrm{Mn}$ consecutive elimination of considerable and inconsiderable outliers increases correlation between their OAES-contents and EDXRF-contents. For most trace elements (Mo, $\mathrm{Zn}, \mathrm{Pb}, \mathrm{Cr}, \mathrm{Ni}, \mathrm{Ba}, \mathrm{V}$ ) elimination of outliers leads to the oppose tendency.

This might be explained by fact that single outliers characterized by extremely high OAEScontents or EDXRF-contents can artificially increase the correlation. Obvious decrease of maximum values of both OAES-contents and EDXRF-contents after elimination of considerable outliers confirms this. For $\mathrm{Pb}, \mathrm{Mo}, \mathrm{V}, \mathrm{Cr}$ this decrease is especially pronounced. Elimination of inconsiderable outliers either does not change maximum values of OAEScontents and EDXRF-contents or changes them to a lower extent.

However, the second stage of elimination often leads to some increase of $\mathrm{R}^{2}$ (and $\mathrm{R}$ ) values, e.g. for $\mathrm{Zn}, \mathrm{Cr}, \mathrm{Ni}, \mathrm{Ba}, \mathrm{V}$.

The question arises which linear regression equations should be used. On our opinion, though the correlation between OAES-contents or EDXRF-contents is supposed to exist also at high concentrations of trace elements, there is insufficient data to use the respective linear regression for prediction. Therefore regression equations after elimination of anomalies seem to be more based.

The necessity to eliminate outliers with high contents is confirmed by the fact that for some elements, e.g. $\mathrm{Pb}, \mathrm{Cu}$, linear regression parameters without any elimination are greatly different from respective parameters after elimination of outliers (Table 2). On the whole, the estimates of linear regression parameters on different stages are rather similar. 
After the elimination of outliers the arrangement of trace elements according to decreasing $\mathrm{R}^{2}$ (and $\mathrm{R}$ ) values is as follows: $\mathrm{Cu}>\mathrm{Zn}>\mathrm{Pb}>\mathrm{Sn}>\mathrm{Cr}>\mathrm{Ni}>\mathrm{Mo}>\mathrm{Ba}>\mathrm{Mn}>\mathrm{V}$ (Fig 1).

Table 2.

Correlation and linear relationship of two different contents of trace elements

\begin{tabular}{|c|c|c|c|c|c|c|}
\hline $\mathbf{E}_{\mathbf{i}}$ & $\mathbf{R}^{2}$ & $\mathbf{R}$ & $\mathbf{N}$ & $\operatorname{Mx}(\mathbf{S}) \backslash \mathbf{M x}(X)$; outliers eliminated & $\mathbf{a}$ & b \\
\hline $\mathrm{Mo}_{1}$ & 0.9870 & 0.9935 & 141 & 178\58.5; & 0.3464 & 0.4014 \\
\hline $\mathrm{Mo}_{2}$ & 0.4455 & 0.6675 & 135 & $\begin{array}{l}\text { 4.3213.44; N21(RDC), N22(RDC), N23(RD), } \\
\text { N24(RD), N04(D), Sn13(D) }\end{array}$ & 0.3869 & 0.2877 \\
\hline $\mathrm{Mo}_{3}$ & 0.4331 & 0.6581 & 136 & 4.32\2.40; N26(D) & 0.3083 & 0.3683 \\
\hline $\mathrm{Zn}_{1}$ & 0.7777 & 0.8819 & 141 & 1000\530; & 0.4933 & 33.549 \\
\hline $\mathrm{Zn}_{2}$ & 0.7271 & 0.8527 & 138 & 720\408; N11(RD), N17(D), Se02(D) & 0.4688 & 37.961 \\
\hline $\mathrm{Zn}_{3}$ & 0.7511 & 0.8667 & 135 & 720\408; Zr26, Zr28, A09a & 0.4712 & 35.237 \\
\hline $\mathrm{Pb}_{1}$ & 0.7751 & 0.8804 & 141 & 914\13100; & 11.859 & -751.48 \\
\hline $\mathrm{Pb}_{2}$ & 0.6961 & 0.8343 & 139 & 189\171; Se04(RDC), Se21(RDC) & 0.6520 & 5.1306 \\
\hline $\mathrm{Pb}_{3}$ & 0.6666 & 0.8165 & 135 & $\begin{array}{l}\text { 165\155; Se05(D), A09(D), Sn17(D), } \\
\text { Zv03(D) }\end{array}$ & 0.6392 & 5.8739 \\
\hline $\mathrm{Cu}_{1}$ & 0.6986 & 0.8358 & 141 & 232\273; & 0.8147 & -6.1007 \\
\hline $\mathrm{Cu}_{2}$ & 0.7326 & 0.8559 & 139 & 128\111; A09(RDC), Sn08(RDC) & 0.4971 & 4.6179 \\
\hline $\mathrm{Cu}_{3}$ & 0.7810 & 0.8837 & 136 & 128\111; Se29, Zr08, A10(D) & 0.5432 & 3.3337 \\
\hline $\mathrm{Cr}_{1}$ & 0.7713 & 0.8782 & 141 & 204195.7; & 0.4532 & 5.7101 \\
\hline $\mathrm{Cr}_{2}$ & 0.4238 & 0.6510 & 138 & 70.1147.3; N21(D), N22(D), Zr12(R) & 0.4663 & 5.1915 \\
\hline $\mathrm{Cr}_{3}$ & 0.4920 & 0.7014 & 133 & 70.1\47.3; N09, Se04, Se17, Zr27, A11 & 0.4749 & 4.4621 \\
\hline $\mathrm{Ni}_{1}$ & 0.5309 & 0.7286 & 141 & 47.6127.8; & 0.3709 & 2.6565 \\
\hline $\mathrm{Ni}_{2}$ & 0.4450 & 0.6671 & 138 & 39.1\16.7; Se04(R), Se09(R), Zr12(RDC) & 0.3013 & 3.6589 \\
\hline $\mathrm{Ni}_{3}$ & 0.4744 & 0.6888 & 135 & 39.1\16.7; N28, Se07, Sn05 & 0.2849 & 3.8154 \\
\hline $\mathrm{Ba}_{1}$ & 0.4701 & 0.6856 & 141 & 908\653; & 0.3418 & 211.2 \\
\hline $\mathrm{Ba}_{2}$ & 0.2330 & 0.4827 & 139 & 624\462; N11(RDC), Zv10(D) & 0.2198 & 248.78 \\
\hline $\mathrm{Ba}_{3}$ & 0.2464 & 0.4964 & 134 & 624\413; N10, N22, Sn2 & 0.2080 & 251.51 \\
\hline $\mathrm{V}_{1}$ & 0.3352 & 0.5790 & 141 & 137\597; & 0.3125 & 3.2083 \\
\hline $\mathrm{V}_{2}$ & 0.0785 & 0.2802 & 138 & 60.6133.3; N21(DC), N22(DC), A10(RDC) & 0.2427 & 5.6373 \\
\hline $\mathrm{V}_{3}$ & 0.0788 & 0.2807 & 136 & 60.6131.2; Zr06, Zr16 & 0.2321 & 5.7675 \\
\hline $\mathrm{Sn}_{1}$ & 0.2926 & 0.5409 & 141 & 49.9\38.0; & 0.3983 & 4.1225 \\
\hline $\mathrm{Sn}_{2}$ & 0.4068 & 0.6378 & 138 & 23.2117.0; N28(RDC), Se28(RC), A20(R) & 0.4642 & 3.5344 \\
\hline $\mathrm{Sn}_{3}$ & 0.5233 & 0.7234 & 135 & 23.2\12.3; $\mathrm{Se} 03, \mathrm{Se} 26, \mathrm{Zv} 03$ & 0.4473 & 3.4330 \\
\hline $\mathrm{Mn}_{1}$ & 0.1630 & 0.4037 & 141 & 977\495; & 0.1599 & 216.48 \\
\hline $\mathrm{Mn}_{2}$ & 0.1731 & 0.4161 & 140 & 977\435; Se09(R) & 0.1559 & 217.28 \\
\hline $\mathrm{Mn}_{3}$ & 0.2132 & 0.4617 & 134 & 977\397; Se02, Se04, Se19, A02, Sn10, Zv02 & 0.1544 & 215.15 \\
\hline
\end{tabular}

Note. $\mathrm{El}_{\mathrm{i}}$ - element and information about elimination of outliers: index 1 - without elimination of outliers, index 2 - after elimination of considerable outliers, index 3 -after elimination of inconsiderable outliers; $\mathrm{R}^{2}$ - coefficient of determination; $\mathrm{R}$ - Pearson correlation coefficient; $\mathrm{N}$ number of observations in linear regression; $\mathbf{M x}(\mathbf{S}) \mathbf{M x}(\mathbf{X})$ - maximum OAES-content and maximum EDXRF-content; estimated values of linear regression parameters: a - coefficient before independent variable, i.e. slope, $b$ - intercept. The outliers are indicated by sample identification numbers with the following additional information given in parentheses: $\mathrm{R}$ - absolute value of standard residual exceeds 3; C - Cook's distance exceeds critical value (0.693) [12], D - deleted residual differs from residual. 
Zinkutė R., Taraškevičius R. CASE STUDY ON THE RELATIONSHIPS BETWEEN SOIL CONTENTS OF SOME HARMFUL CHEMICAL ELEMENTS DETERMINED BY DIFFERENT EQUIPMENT
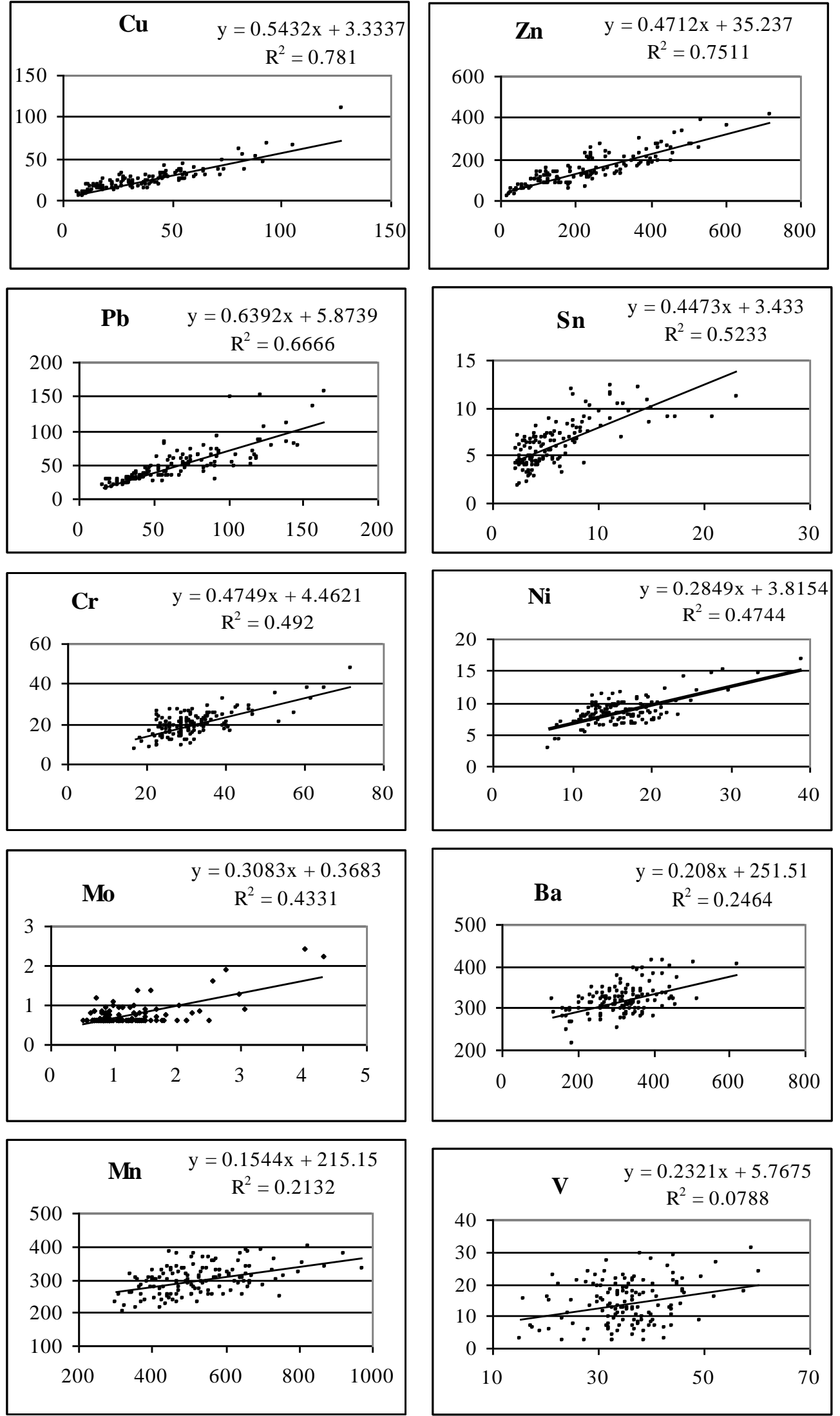

Fig.1. Correlation between trace element contents determined by different equipment 
It is obvious that for chalcophiles $(\mathrm{Cu}, \mathrm{Zn}, \mathrm{Pb}, \mathrm{Sn})$ the correlation between OAES-contents and EDXRF-contents is higher than for siderophiles or lithophiles. The highest slope of linear regression is characteristic of $\mathrm{Pb}(0.639)$. It is followed by $\mathrm{Cu}(0.543)$, other trace elements are arranged as follows: $\mathrm{Cr}(0.475), \mathrm{Zn}(0.471), \mathrm{Sn}(0.447), \mathrm{Mo}(0.308), \mathrm{Ni}(0.285), \mathrm{V}(0.232)$, $\mathrm{Mn}(0.213), \mathrm{Ba}(0.208)$. For most siderophile or lithophile trace elements (except $\mathrm{Cr}$ ) the slope is lower.

As concerns major elements, the coefficients of determination are not always sufficiently high and Pearson correlation coefficients are not always significant, especially for $\mathrm{Al}$, also for $\mathrm{Mg}$ before elimination of anomalies (Table 3). Most probably, there were rough mistakes of $\mathrm{Mg}$ determination by OAES in 2 samples. Linear regression performed according to primary data of major elements (without any elimination of outliers) showed significant $(p<0.05)$ values of ANOVA F-test for $\mathrm{Ca}, \mathrm{Mg}$ and $\mathrm{Fe}$, both parameters (slope and intercept) being also significant $(\mathrm{p}<0.05)$. For $\mathrm{Al}, \mathrm{F}$-test of ANOVA and t-test for slope being equal to zero resulted in insignificant $p$-values ( $p>0.05)$. Elimination of anomalies slightly improved the correlation between OAES-contents and EDXRF-contents of $\mathrm{Al}$ and it became significant $(\mathrm{p}<0.05)$. Still it is hardly possible to predict EDXRF-contents of $\mathrm{Al}$ according to its OAEScontents or additional data are necessary. As for most trace elements, for Fe the elimination of outliers lead to decrease of $\mathrm{R}^{2}$ (and $\mathrm{R}$ ) values as well as considerable decrease of its maximum OAES-contents and EDXRF-contents. For other 3 major elements the tendency was the opposite. According to decreasing values of $\mathrm{R}^{2}$ (and $\mathrm{R}$ ) after the second stage of elimination of outliers, the major elements are arranged as follows: $\mathrm{Ca}>\mathrm{Mg}>\mathrm{Fe}>\mathrm{Al}$. The same arrangement of major elements is according to regression slope values after the second stage of elimination of outliers.

Table 3.

Correlation and linear relationship of two different contents of major elements

\begin{tabular}{|c|c|c|c|c|c|c|}
\hline $\mathbf{E} \mathbf{l}_{\mathbf{i}}$ & $\mathbf{R}^{2}$ & $\mathbf{R}$ & $\mathbf{N}$ & $\operatorname{Mx}(S) \backslash M x(X)$; outliers eliminated & $\mathbf{a}$ & b \\
\hline $\mathrm{Ca}_{1}$ & 0.7096 & 0.8424 & 141 & $46800 \backslash 52000$ & 0.8414 & 4227.7 \\
\hline $\mathrm{Ca}_{2}$ & 0.7124 & 0.8440 & 139 & 36800\35600; Se03(RDC), Se09(RD) & 0.8670 & 3775.3 \\
\hline $\mathrm{Ca}_{3}$ & 0.7378 & 0.8590 & 137 & 36800〈35600; N22, Se01 & 0.8701 & 3578.7 \\
\hline $\mathrm{Mg}_{1}$ & 0.0522 & 0.2285 & 141 & 114000\10100; & 0.0314 & 4779 \\
\hline $\mathrm{Mg}_{2}$ & 0.6278 & 0.7923 & 138 & 1230018010; Se09(R), A02(R), A07(DC) & 0.4435 & 1779.1 \\
\hline $\mathrm{Mg}_{3}$ & 0.5682 & 0.7538 & 133 & 12300\7510; A03, A04, A05, Se13, Se15 & 0.3857 & 2235.5 \\
\hline $\mathrm{Fe}_{1}$ & 0.3469 & 0.5890 & 141 & $32800 \backslash 23800$ & 0.3145 & 3805.4 \\
\hline $\mathrm{Fe}_{2}$ & 0.2684 & 0.5181 & 139 & 24800\13000; Se09(RDC), A03(RD) & 0.2188 & 5315.1 \\
\hline $\mathrm{Fe}_{3}$ & 0.2503 & 0.5003 & 138 & 24800\13000; A02 & 0.2031 & 5595.3 \\
\hline $\mathrm{Al}_{1}$ & 0.0267 & 0.1634 & 141 & 52300\27300; & 0.0763 & 17574 \\
\hline $\mathrm{Al}_{2}$ & 0.0203 & 0.1425 & 139 & 50700\26800;N25(D), Se17(R) & 0.0656 & 17899 \\
\hline $\mathrm{Al}_{3}$ & 0.0296 & 0.1720 & 132 & $\begin{array}{l}\text { 50700L24700; N08, Se19, Zr05, Zr14, } \\
\text { Zr25, Zv03, Zv09 }\end{array}$ & 0.0658 & 17602 \\
\hline
\end{tabular}

Note: explanation is the same as in Table 3.

\section{Conclusions}

Most of chemical elements studied, except $\mathrm{Ca}$, $\mathrm{Sn}$ and $\mathrm{Ba}$, are characterised by significantly lower EDXRF-contents than OAES-contents. Unlike most elements, the EDXRF-content of $\mathrm{Ca}$ is significantly higher than OAES-content, Sn has also a tendency of higher EDXRFcontent. Such differences can be explained by different standard reference materials used for re-calibration of measurements of total element contents obtained by different equipment. Continuous participation of IGG in WEPAL ISE program ensured increase of available ISE samples which can be used as standard reference materials for re-calibration of measurements 
obtained by EDXRF. Preliminary comparison of relative standard measurement uncertainties of both methods for mean values of two reference materials has shown that most trace elements studied ( $\mathrm{Ba}, \mathrm{Cr}, \mathrm{Cu}, \mathrm{Ni}, \mathrm{Mn}, \mathrm{Pb}, \mathrm{V}, \mathrm{Zn}$ ), except $\mathrm{Sn}$ and $\mathrm{Mo}$, are characterised by lower uncertainty of EDXRF measurements. Due to these reasons EDXRF-contents are more reliable. However, huge problem of their application in practice arises, when it is necessary to estimate the danger category of contaminated urban soil, because all previous background values for soil were calculated on the basis of OAES measurements. According to the ratio of median EDXRF-content to median OAES-content the arrangement of potentially harmful elements is as follows: $\mathrm{V}(0.40)<\mathrm{Ni}(0.52)<\mathrm{Mo}(0.57)<\mathrm{Zn}(0.58)<\mathrm{Mn}(0.59)<\mathrm{Cr}(0.63)$ $<\mathrm{Cu}(0.64)<\mathrm{Pb}(0.73)<\mathrm{Ba}(0.99)<\mathrm{Sn}(1.21)$. It is obvious that the old background values of $\mathrm{V}$, $\mathrm{Ni}, \mathrm{Mo}, \mathrm{Zn}, \mathrm{Mn}, \mathrm{Cr}, \mathrm{Cu}, \mathrm{Pb}$ estimated according OAES-content are absolutely unsuitable for calculation of concentration coefficients $\mathrm{Kk}$ and additive contamination index $\mathrm{Zd}$ (which depends on $\mathrm{Kk}$ ). If this fact is ignored, theunderestimation of soil contamination categories according to $\mathrm{Zd}$ threatens. Therefore the determination of background EDXRF-contents on uncontaminated territories is necessary. Since for all trace elements two contents determined by different equipment are significantly correlated, simple linear regression equations for prediction of EDXRF-content according to OAES-content might be useful. These equations differ before and after the elimination of outliers. The latter relationships indicate that for chalcophiles the correlation between OAES-contents and EDXRF-contents is higher than for siderophiles or lithophiles. Prediction of some major elements $(\mathrm{Ca}, \mathrm{Mg}, \mathrm{Fe})$ is also possible according to linear regression equations. However, prediction of $\mathrm{Al}$ according to available data is problematic.

\section{References}

1. Lis, J., Pasieczna, A., Taraškevičius R. Total and partial extraction of selected elements in soil of the Poland - Lithuania borderland. Journal of Geochemical Exploration, Vol. 66, Issues 1-2, 1999, p. 211-217.

2. Kadūnas, V., Budavičius, R., Gregorauskienè, V., Katinas, V., Kliaugienè, E., Radzevičius, A., Taraškevičius, R. Geochemical atlas of Lithuania. Vilnius. Institute of Geology, Lithuanian Geological Survey, 1999, 90 p.: 18 tables + 162 maps (in Lithuanian and English).

3. Kadūnas, V., Budavičius, R., Katinas, V., Kliaugienè, E., Radzevičius, A., Zinkutè, R. Geochemical atlas of Mažeikiai district. Municipality of Mažeikiai district, Institute of Geology, Vilnius-Mažeikiai, 2001, 87 p.: 6 tables+29 maps (in Lithuanian and English).

4. Radzevičius, A., Gregorauskienè, V., Kadūnas, V., Putys, P. 2004. Geochemical atlas of Panevėžys county. Administration of Panevėžys county, Institute of Geology and Geography, Lithuanian Geological Survey, Vilnius-Panevėžys, 2004, 123 p.: 10 tables + 54 maps (in Lithuanian and English).

5. Radzevičius, A., Budavičius, R., Kadūnas, V., Katinas, V., Zinkute, R., Tverkute, Z. Geochemical atlas of Panevėžys. M 1:25000. Institute of Geology, Ecological department of Panevėžys municipality, VilniusPanevėžys, 1997, 18 p.: 7 tables +25 maps (in Lithuanian and English).

6. Taraškevičius, R. 2000. Sunkieji metalai Vilniaus miesto Naujamiesčio, Senamiesčio, Šnipiškių, Žirmūnu, Žvèryno ir Antakalnio seniūnijų dirvožemiuose. Aplinkos inžinerija, T. 8. Nr. 3, 2000, p. 137-145 (in Lithuanian).

7. Jankauskaitė, M., Taraškevičius, R., Zinkutė, R., Veteikis, D. Relationship between landscape selfregulation potential and topsoil additive contamination by trace elements in Vilnius city. Journal of environmental engineering and landscape management, Vol.16. No. 1, 2008, p. 5-14.

8. Taraškevičius, R. Klaipèdos prieuosčio dirvožemio ir grunto geohigieninis vertinimas. Jūros ir krantų tyrimai - 2008. Konferencijos medžiaga. 2008 balandžio 09-11 Palanga. Klaipèda, 2008, p. 143-147 (in Lithuanian).

9. Zinkute, R., Taraškevičius, R., Jankauskaite, M. 2009. Variation of accumulating associations in topsoil of the oldest part of Vilnius. Vide. Tehnologija. Resursi. VII starptautiskās zinātniski praktiskās konferences materiāli, 2009. gada 25.-27. jūnijs. Rēzekne, 2009, p. 241-248.

10. Taraškevičius, R., Zinkute, R., Jankauskaite, M. Differences of Vilnius topsoil contamination in the Neris River valley due to anthropogenic factors. Geologija, Vol. 50, No. 3(63), 2008, p. 135-142.

11. Zinkutè, R. Taraškevičius, R., Želvys, T. Major elements as possible factors of trace element urban pedochemical anomalies. Central European Journal of Chemistry, Vol. 9, Issue 2, 2011, p. 337-347. Doi: 10.2478/s11532-011-0012-z.

12. Čekanavičius, V., Murauskas, V. Statistika ir jos taikymai. II. Vilnius: TEV, 2004, 272 p. (in Lithuanian). 